\title{
Zeszyty PRASOZNAWCZE
}

Kraków 2018, T. 61, nr 3 (235), s. $529-544$

doi: $10.4467 / 22996362$ PZ.18.032.10134

www.ejournals.eu/Zeszyty-Prasoznawcze/

\section{PRECYZYJNE PROFILOWANIE} UŻYTKOWNIKÓW FACEBOOKA CZY WRÓŻENIE Z FUSÓW? KRYTYCZNA ANALIZA DZIALANIA ALGORYTMU STWORZONEGO PRZEZ MICHAŁA KOSIŃSKIEGO I WYKORZYSTANEGO PRZEZ FIRME CAMBRIDGE ANALYTICA

\author{
(1D) http://orcid.org/0000-0001-6946-7555 \\ URSZULA DOLIWA, ŁUKASZ GROCHULSKI, PAULINA \\ SOBOLEWSKA, KATARZYNA ŁOCHOWSKA, KAMILA MOTYKA, \\ KAROLINA WOJDYNA, KAMIL CHOROSZEWSKI
}

\begin{abstract}
Precise profiling of Facebook users or reading tea leaves? Critical analysis of the algorithm created by Michal Kosiński and used by Cambridge Analytica

In the article the operation of the tool ApplyMagicSauce.com was analyzed. It was created by researchers in order to make the profilization of social media users possible and became famous when the principles of operation of this tool were used by the company Cambridge Analytica, involved in the presidential campaign of Donald Trump as well as the supporters of the British withdrawal from the European Union. A group of six people consisting of one lecturer and students of journalism and social communication decided to undergo a study using this tool, providing data from their private profiles on Facebook. The goal was to show how the tool works and the critical analysis of its effectiveness. The study was conducted in November 2017.
\end{abstract}

Keywords: Internet, Facebook, social media, algorithm, Big Data

$\bowtie \quad$ Adres do korespondencji: urszula.doliwa@uwm.edu.pl 
Rozwój sieci był początkowo postrzegany jako wielka szansa na dostęp obywateli do mediów, na swobodę wypowiedzi i powszechny charakter debaty publicznej na temat ważnych dla społeczeństwa spraw. Z biegiem lat stawał się on jednak przedmiotem coraz większej troski ze strony ekspertów, którzy zaczęli wskazywać również na istotne zagrożenia z nim związane. Szerząca się mowa nienawiści, rozpowszechnianie nieprawdziwych informacji czy też niedostateczna ochrona naszych danych, które masowo trafiają do Internetu, to tylko niektóre wyzwania, przed którymi stoi współczesny świat.

Po początkowym zachwycie możliwościami, jakie daje Internet, zaczęły się pojawiać pytania, do czego i przez kogo wiedza tam gromadzona zostanie wykorzystana. Problem jest tym bardziej istotny, że regulacje prawne nie nadążają za tempem rozwoju sieci - pole do popisu dla tych, którzy chcieliby nasze dane wykorzystać, stało się bardzo szerokie.

Jednym $z$ bardziej aktywnych podmiotów biorących udział w debacie na temat zagrożeń związanych z korzystaniem z sieci jest Rada Europy, ale także UNESCO czy Parlament Europejski. Ważnym punktem wyjścia w wielu dokumentach Rady Europy na ten temat są prawa człowieka. Były one między innymi podstawą do opracowania przewodnika po prawach człowieka dla użytkowników Internetu (Rada Europy 2014). Szczegóły tego zagadnienia zostały również wyjaśnione w załączniku do Rekomendacji na temat wolności Internetu z 13 kwietnia 2016 roku (Rada Europy 2016). Do tych podstawowych praw człowieka w kontekście Internetu zaliczono: wolność wypowiedzi, wolność zgromadzeń i zrzeszania się, prawo do prywatności i ochrony danych osobowych oraz demokratyczny nadzór nad rozwojem sieci. W ich omówieniu możemy znaleźć przypomnienie, że prawo do poszanowania życia prywatnego i rodzinnego to jedno z praw zagwarantowanych w artykule 8. Europejskiej Konwencji Praw Człowieka (Europejski Trybunał Praw Człowieka 1950). Z punktu widzenia tego artykułu na szczególną uwagę zasługują zwłaszcza dwa ostatnie punkty rekomendacji: prawo do prywatności i ochrony danych osobowych oraz demokratyczny nadzór nad rozwojem sieci.

Bardzo ważnym dokumentem, który wprowadza istotne zmiany w podejściu do ochrony danych, jest Rozporządzenie z 27 kwietnia 2016 roku w sprawie ochrony osób fizycznych w związku z przetwarzaniem danych osobowych i w sprawie swobodnego przepływu takich danych (Parlament Europejski, Rada UE 2016). Każda jednostka gromadząca dane musi dokonać analizy przetwarzanych treści, ustalić, czy przetwarza je zgodnie z zasadą legalności, rzetelności i przejrzystości, z zasadą ograniczenia celu przetwarzania danych, z zasadą minimalizacji danych, prawidłowości danych, ograniczenia przechowania danych, integralności i poufności danych oraz z zasadą rozliczalności. Konieczne jest też oszacowanie ryzyka w związanego $\mathrm{z}$ gromadzeniem danych osobowych oraz dokonanie oceny skutków ewentualnego ich wycieku. O fakcie takiego wycieku trzeba informować. Bardzo ważną zmianą z punktu widzenia użytkowników sieci jest fakt, że wiele firm, wdrażając dobre praktyki w zakresie ochrony danych osobowych w kontekście regulacji RODO, w tym Facebook, występuje do nas, o tzw. 
zgodę na profilowanie, czyli na wnioskowanie o jednych danych osobowych na podstawie drugich - najczęściej w celu dopasowywania do naszych potrzeb reklam (Maroszok 2018). W praktyce jednak, nie zgadzając się na profilowanie, wyrażamy w ten sposób sprzeciw wobec praktyk śledzenia naszych zachowań w sieci.

Ochrona naszej prywatności wiąże się nieodłącznie z wykorzystaniem zasobów Big Data, elektronicznych śladów w sieci, ale także poza nią: zakupów za pomocą karty kredytowej, każdego zapytania w wyszukiwarce Google, każdego ruchu telefonu komórkowego w kieszeni, każdego polubienia (Łódzki 2016). Odpowiednie algorytmy coraz śmielej zaczęły jednak ingerować w nasze życie nie tylko na poziomie big, ale także mikro - każdemu z nas zaczęły wyświetlać odpowiednio sprofilowane wyniki wyszukiwań, a w ślad za nimi - reklamy (Łódzki 2016). Powszechne zaniepokojenie budzi wykorzystanie tych danych, które nie byłoby możliwe, gdyby nie inteligentne algorytmy, za pomocą których z tych ogromnych zasobów wyłuskiwane są istotne informacje. Jak słusznie zauważa Jakub Nowak, „kultura i polityka są dziś współkształtowane przez algorytmy nowych mediów. Algorytm jest technologią i, jak każda technologia, jest zasobem. Pytanie, w czyich rękach i w jakich procesach" (Nowak 2017, s. 369).

$\mathrm{W}$ artykule postanowiliśmy przeanalizować działanie jednego z takich algorytmów, którego wykorzystanie wzbudziło ogromne zainteresowanie, ale też kontrowersje na całym świecie. Jego twórcą jest Polak - Michał Kosiński - informatyk i psycholog, specjalizujący się w eksploracji danych i psychometrii. W 2014 roku uzyskał doktorat z psychologii na Uniwersytecie Cambridge, w ramach którego pracował nad lepszym zrozumieniem roli internetowych sieci społecznościowych w środowisku korporacyjnym. Michał Kosiński był również konsultantem ds. badań w dziale usług internetowych i reklamy w Microsoft Research Cambridge oraz zastępcą dyrektora University of Cambridge Psychometrics Center. Po uzyskaniu stopnia doktora przeniósł się do Bay Area w San Francisco. Spędził także rok jako stypendysta na Wydziale Informatyki w Stanford. Obecnie, od 2015 roku, jest adiunktem w zakresie zachowań organizacyjnych w Stanford Graduate School of Business (Stanford Graduate School of Business 2018).

Jednym z najważniejszych osiągnięć badawczych Kosińskiego była koordynacja projektu myPersonality, który obejmował globalną współpracę z ponad 200 naukowcami. Głównym celem projektu była szczegółowa analiza profili psychodemograficznych ponad 8 milionów użytkowników Facebooka, czyli zbadanie związku między cechami psychologicznymi a zachowaniem online. $\mathrm{W}$ badaniu wzięło udział ponad 150 zespołów badawczych z całego świata (Kosiński 2018). Rezultatem była aplikacja, która ukazała się na stronie uniwersytetu i jest dostępna do dziś pod adresem ApplyMagicSauce.com.

Pomysł na aplikację pojawił się w momencie, kiedy Facebook po raz pierwszy otworzył się na aplikacje innych firm. Dr Kosiński i współpracujący z nim analityk do spraw Big Data dr David Stillwell poprosili użytkowników Facebooka o wypełnienie ankiet składających się ze 100 pytań. Okazało się, że zadziwiająco 
chętnie wypełniali oni test psychologiczny. Były miesiące, w których liczba gości przekraczała milion (Elizabeth 2018). Wyniki testu psychologicznego skorelowano z informacjami pozyskanymi z Facebooka i dzięki olbrzymiej liczbie zgromadzonych danych udało się stworzyć narzędzie, za pomocą którego zdumiewająco trafnie można określić cechy danej osoby tylko na podstawie określonych zachowań na Facebooku.

Michał Kosiński udowodnił, że jest możliwe zastąpienie tradycyjnej ankiety algorytmem, który obserwuje, jakie ślady cyfrowe osoba badana pozostawia na Facebooku, i na tej podstawie przedstawia jej profil psychodemograficzny. Analizujący dane algorytm często, jak chętnie deklaruje sam Kosiński, wie więcej na temat badanego niż bliska osoba. Badania Kosińskiego wywarły istotny wpływ zarówno na gospodarkę, politykę, jak i środowisko akademickie. W 2013 roku Kosiński znalazł się w gronie 50 najbardziej wpływowych osób w Big Data od DataIO i IBM, a trzy z jego artykułów znalazły się wśród „Top 100 Papers That Most Caught the Public Imagination" (w 2013 i 2015 roku) (Stanford Graduate School of Business 2018).

Badania Kosińskiego, bez jego wiedzy i zgody, zostały użyte do celów politycznych. Za internetową kampanią wyborczą Trumpa i za kampanią Brexitu stala ta sama firma - Cambridge Analytica, która twórczo postanowiła wykorzystać ustalenia polskiego badacza. Zwycięstwo Trumpa w wyborach prezydenckich i doprowadzenie do zwycięstwa w referendum zwolenników wystąpienia Wielkiej Brytanii z Unii Europejskiej zostały potraktowane jako dowody na skuteczność metod opartych na analizie Big Data w marketingu politycznym - za ich pomocą segmentowano wyborców i wysyłano im odpowiednio dobrane komunikaty (Szymaniak 2018). Przy okazji jednak okazało się, że firmie udało się na przykład pozyskać dostęp do profili nie tylko osób, które zgodziły się wziąć udział w bliźniaczo podobnych do tego przeprowadzonego przez Kosińskiego badaniu This Is Your Digital Life, ale także danych ich znajomych - w sumie kilkudziesięciu milionów użytkowników Facebooka na całym świecie (Ćwiklak 2018). Wywołało to sprzeciw użytkowników Facebooka i doprowadziło do zamknięcia firmy Cambridge Analytica (mih, pcg 2018).

Warto dodać, że te wydarzenia wywołały też poważny kryzys zaufania dotyczący bezpieczeństwa naszych danych umieszczanych na portalu Facebook. Jego twórca, Mark Zuckerberg, musiał się tłumaczyć z wycieku danych użytkowników między innymi przed Kongresem Stanów Zjednoczonych (10 kwietnia 2018 roku). W sieci rozpoczęła się akcja protestacyjna użytkowników tego medium społecznościowego pod hasłem \#deletefacebook. Jedną z konsekwencji afery może być utrudniony dostęp do danych dla środowiska naukowego - badaczy zainteresowanych na przykład badaniem wpływu mediów społecznościowych na demokrację. Zasady współpracy portalu Facebook z akademikami są teraz również przedmiotem dyskusji (Gluckman 2018).

Warto więc przyjrzeć się, jak działa algorytm Kosińskiego, którego użytkowanie pociągnęło za sobą tak daleko idące skutki. Zespół badaczy składający się 
z wykładowcy i studentów dziennikarstwa i komunikacji społecznej postanowił przetestować dostępne na stronie ApplyMagicSauce.com narzędzie do profilowania na podstawie danych udostępnianych na portalu Facebook.

\section{Jak działa algorytm stworzony przez Kosińskiego}

Narzędzie dostępne na stronie ApplyMagicSauce.com, zbierające i analizujące dane, których użytkownik dostarcza poprzez swoją aktywność w dwóch ważnych mediach społecznościowych, przewiduje na ich podstawie cechy psychodemograficzne danej osoby. Program obecny na stronie ApplyMagicSauce.com daje możliwość wyboru konkretnego medium społecznościowego, na podstawie którego będzie przeprowadzał obliczenia - Facebooka (ta możliwość jest w tej chwili wyłączona) lub Twittera. Zespół badawczy postanowił przeprowadzić badania, opierając się na portalu Facebook, z pominięciem Twittera, z uwagi na niewielką aktywność uczestników badania na tej platformie lub jej brak. Po wybraniu portalu społecznościowego program dokonuje obliczeń i następuje prezentacja wyników w postaci trzech raportów:

a) na podstawie wszystkich źródeł - algorytm przedstawia wyniki na podstawie aktywności dokonywanych przez użytkownika na portalu - ,polubien”” oraz zamieszczonych postów. Należy zaznaczyć, że podczas wykonywania obliczeń program nie uwzględnia tak zwanych reakcji na posty innych użytkowników portalu, a jedynie „polubienia” poszczególnych stron;

b) na podstawie samych polubień;

c) na podstawie samych postów.

W pierwszym wariancie, w raporcie na podstawie zarówno polubień, jak i postów, określona zostaje:

a) tak zwana płeć psychologiczna na podstawie naszego „stopnia androgeniczności";

b) wiek;

c) „Big 5 Personality” - pięć głównych cech naszej osobowości, takich jak: neurotyczność, ekstrawersja, sumienność, otwartość na doświadczenie oraz ugodowość (Costa, McCrae 1992). Każdy element posiada dwa skrajne bieguny, na przykład na jednym znajduje się informacja o najwyższym stopniu nastawienia na rywalizację, a na drugim skłonność do pracy w grupie i obdarzania zaufaniem innych (w przypadku ugodowości). Pośrodku znajduje się wartość 50\%, która wskazuje na równowagę między obydwoma biegunami;

d) inteligencja - przedstawiona w wartościach procentowych - im większa wartość, tym prawdopodobnie poziom inteligencji użytkownika jest wyższy;

e) satysfakcja z życia - przedstawiona w wartościach procentowych - im wyższa wartość, tym większa satysfakcja z życia; 
f) potencjał przywódczy - przedstawiony w wartościach procentowych - im wyższa wartość, tym większe predyspozycje do zarządzania;

g) typ osobowości według Junga, który wyróżnił 16 typów osobowości, będących wypadkową różnych kombinacji następujących cech:

- Ekstrawersja (E) lub Introwersja (I)

- Poznanie (S) lub Intuicja (N)

- Myślenie (T) lub Odczuwanie (F)

- Osądzanie (J) lub Obserwacja (P)

h) preferencje seksualne;

i) poglądy polityczne oraz religijne - wyrażone za pomocą diagramów kołowych;

j) edukacja - wyrażona w wartościach procentowych; przedstawiono 12 dziedzin nauki/sztuki;

k) status związku - wyrażony za pomocą diagramu kołowego, za pomocą którego przedstawiono prawdopodobieństwo bycia w związku i jego statusu.

Wykorzystując do obliczenia jedynie polubienia, program przedstawia wyniki w postaci takich samych, wyżej wymienionych elementów (pomija się jedynie przewidywany wiek respondenta).

Warto podkreślić, że w przypadku kluczowych dla profilowania naszej osoby „polubień” nie są brane pod uwagę wszystkie polubienia, a jedynie część, która w algorytmie została uznana za "znaczące”. A więc to konkretne „polubienia” sprawiały, że algorytm uznawał nas na przykład za bardziej lub mniej inteligentnych - inne zaś zupełnie pomijał. Wśród wyświetlanych w podsumowaniu badania znaczących polubień znalazły się na przykład profile znanych marek, programów telewizyjnych, napojów czy artystów i muzyków.

Najmniej rozbudowany charakter miały raporty sporządzane jedynie na podstawie postów użytkowników. W zestawie danych znalazły się takie informacje, jak:

a) wiek

b) płeć psychologiczna;

c) „Big 5 Personality”;

d) potencjał dowódczy;

e) typ osobowości według Junga.

Ze strony ApplyMagicSauce.com można też przejść do testu psychologicznego, który wypełniali i wciąż wypełniają internauci, a który stał się podstawą stworzenia algorytmu. Zawiera on aż 100 pytań w języku angielskim, na które użytkownicy badania starali się odpowiedzieć, by później porównać wyniki $\mathrm{z}$ tymi uzyskanymi w wyniku pracy algorytmu. Po przeprowadzeniu testu psychologicznego otrzymujemy obraz naszej osobowości wyrażony w postaci „wielkiej piątki” i krótki opis osobowości oparty na modelu Junga. 


\section{Metodologia badań}

W badaniu wzięło udział sześć osób. W tym samym czasie wyraziły one zgodę na wykorzystanie swoich prywatnych profili na Facebooku do wygenerowania raportów za pomocą narzędzia ApplyMagicSauce.com. W przypadku niektórych badanych liczba interesujących z punktu widzenia algorytmu ,polubień” okazała się jednak zbyt mała, by wygenerować szczegółowy raport. Co ciekawe, w drugim z raportów, jedynie na podstawie polubień, nie były wykorzystywane wszystkie polubienia brane pod uwagę w raporcie pierwszym. W przypadku wszystkich badanych udało się jednak wygenerować raport na podstawie postów.

Tabela 1. Zestawienie danych wziętych pod uwagę podczas badania

\begin{tabular}{|l|c|c|c|c|c|c|}
\hline & $\begin{array}{c}\text { Badany } \\
\mathbf{1}\end{array}$ & $\begin{array}{c}\text { Badany } \\
\mathbf{2}\end{array}$ & $\begin{array}{c}\text { Badany } \\
\mathbf{3}\end{array}$ & $\begin{array}{c}\text { Badany } \\
\mathbf{4}\end{array}$ & $\begin{array}{c}\text { Badany } \\
\mathbf{5}\end{array}$ & $\begin{array}{c}\text { Badany } \\
\mathbf{6}\end{array}$ \\
\hline $\begin{array}{l}\text { Liczba wszystkich } \\
\text { polubień } \\
\text { wykorzystanych } \\
\text { w badaniu } \\
\text { ogólnym (posty } \\
\text { i polubienia) }\end{array}$ & 142 & 217 & 364 & 1010 & 5675 & 63 \\
\hline $\begin{array}{l}\text { Liczba polubień } \\
\text { wykorzystanych } \\
\text { do badania } \\
\text { szczegółowego } \\
\text { (na podstawie } \\
\text { polubień) }\end{array}$ & $\mathrm{X}$ & 217 & 37 & 1010 & 5093 & $\mathrm{X}$ \\
\hline $\begin{array}{l}\text { Liczba postów } \\
\text { poddanych badaniu }\end{array}$ & 24 & 206 & 101 & 50 & 582 & 25 \\
\hline
\end{tabular}

Źródło: badania własne.

Wszyscy badani wypełnili także test psychologiczny dostępny na stronie https://discovermyprofile.com/personality.html, który stał się podstawą do przygotowania algorytmu. $\mathrm{W}$ teście psychologicznym to uczestnik badania musiał odpowiedzieć na 100 pytań dotyczących postrzegania świata, podejmowania decyzji i znajomości siebie. Istniało więc ryzyko, że osoba biorąca udział w badaniu może udzielić złej odpowiedzi, bo nie do końca zna siebie samą. Z drugiej jednak strony, w przypadku tych, którzy sumiennie podeszli do zadania, test psychologiczny powinien być znakomitym narzędziem służącym do określenia naszego profilu psychologicznego. Badanie prowadzono 16 listopada 2018 roku. 


\section{Zależność między polubieniami konkretnych profili a cechami osobowości}

Najbardziej rozbudowane i interesujące z punktu widzenia zespołu badawczego raporty udało się wygenerować na podstawie samych polubień. Na uwagę zasługuje fakt, że umieszczono w nich informacje, jakie polubienia mogły świadczyć o konkretnych cechach. W przypadku niektórych osób biorących udział w badaniu liczba interesujących z punktu widzenia algorytmu polubień okazała się jednak zbyt mała, by taki raport przygotować. Pod uwagę wzięto więc raporty czterech osób, które udało się wygenerować. W artykule pod lupę wzięto tylko niektóre wyniki - te, które zespołowi badawczemu wydały się szczególnie interesujące i ważne. Polubienia przyporządkowano do następujących kategorii: marki odzieżowe, produkty i usługi kosmetyczne, produkty i usługi spożywcze, produkty elektroniczne, marki motoryzacyjne, muzycy, media, inni artyści i inne.

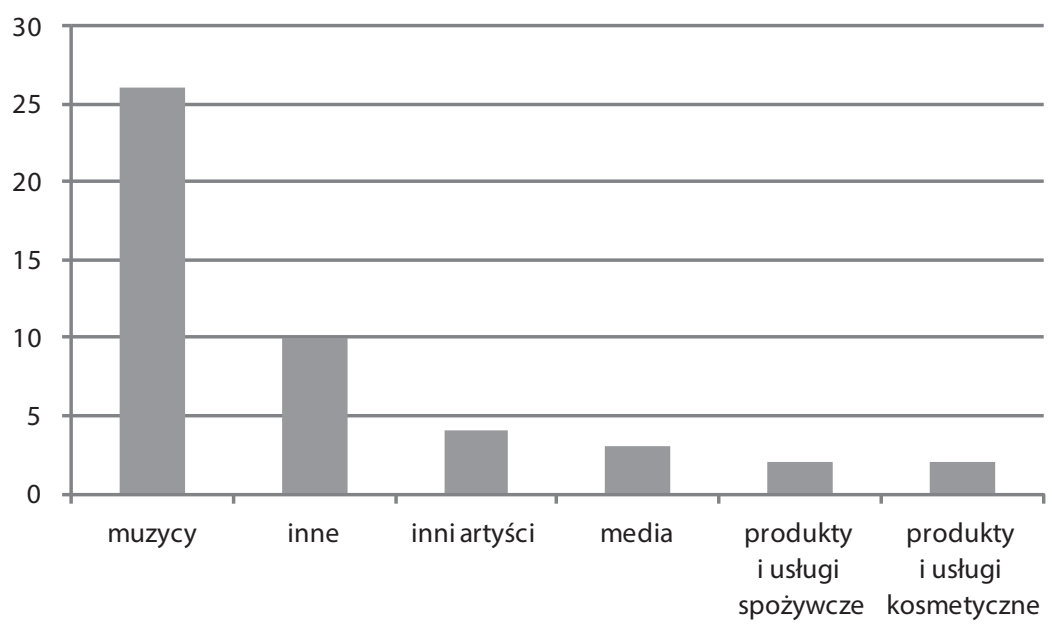

Wykres 1. Zestawienie polubień wykorzystanych w przygotowaniu portretu psychologicznego

Źródło: badania własne.

Jak się okazuje, w przeważającej mierze tworzenie portretów psychologicznych na podstawie polubień zostało oparte na naszych preferencjach muzycznych - wykorzystano aż 26 polubień profili związanych z muzyką, na drugim miejscu znalazła się kategoria inne (10) oraz inni artyści (4). Polubienia w pozostałych kategoriach zostały wykorzystane incydentalnie. 


\section{Inteligencja}

Aby określić stopień inteligencji i wskazać, które polubienia wskazują na niski, a które na wysoki stopień możliwości intelektualnych, algorytm wykorzystał łącznie 20 różnych polubień czterech osób, w przypadku których stworzenie pogłębionych profili okazało się możliwe. Były to polubienia następujących stron: MAC Cosmetics, Starbucks, The Rolling Stones, Disturbed, Kings of Leon, Black Sabbath, Korn, My Chemical Romance, Evanescence, T.I., Eminem, Rihanna, Marilyn Monroe, Will Smith, Megan Fox, „America's Next Top Model”, „Inception”, „How I Met Your Mother”, Harry Potter, „The Lord of the Rings Trilogy”.

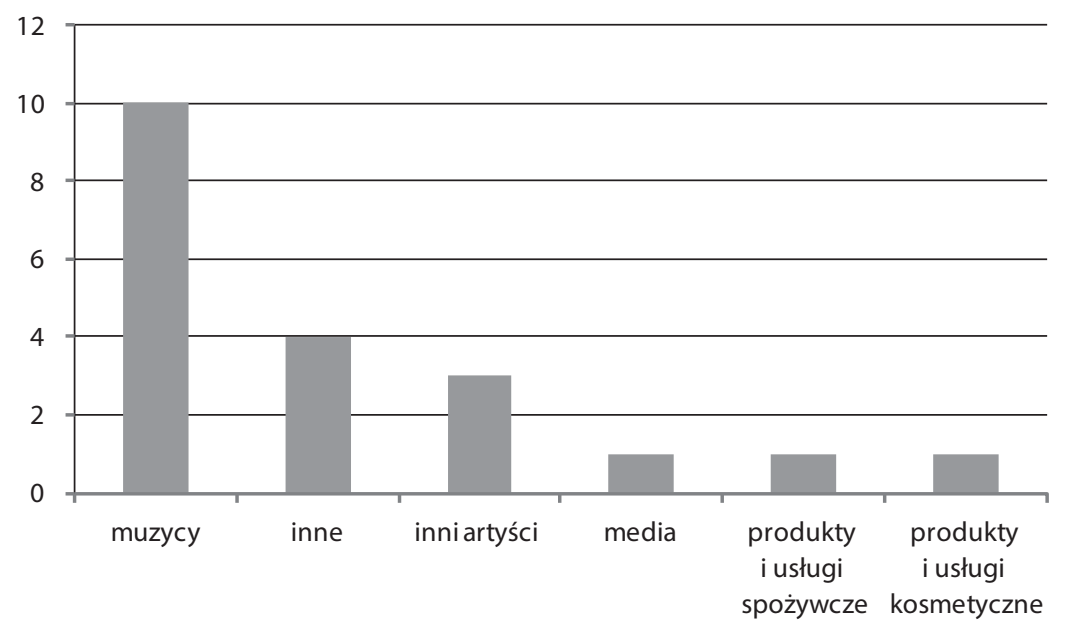

Wykres 2. Zestawienie polubień wykorzystanych do określenia poziomu inteligencji

Źródło: badania własne.

Wśród polubień wskazujących na wysoki poziom inteligencji najwięcej zaliczono do kategorii „inne” - cztery strony. Były to głównie seriale i filmy, np. strona filmowej trylogii „Władca Pierścieni” w reżyserii Petera Jacksona, filmu „Incepcja” czy serialu „Jak poznałem waszą matkę”. O naszej inteligencji dobrze świadczyć miało również polubienie stron znanych aktorów: Willa Smitha, Megan Fox, Marilyn Monroe czy postaci Harry'ego Pottera. Do zbioru polubień wskazujących na wysoki stopień inteligencji zaliczono też te dotyczące muzyków: The Rolling Stones i T.I. Na liście znalazł się również program telewizyjny „America's Next Top Model” oraz dwa razy „The Lord of the Rings Trilogy” i kosmetyki MAC - w sumie 11 profili facebookowych. O niskim poziomie inteligencji świadczyły przede wszystkim polubienia określonych zespołów czy muzyków (Disturbed, Kings of Leon, Black Sabbath, Korn, My Chemical Ro- 
mance, Evanescence, Eminem, Rihanna) oraz strony poświęconej sieci kawiarni Starbucks.

\section{Preferencje seksualne i status związu}

Do określenia preferencji seksualnych czterech osób, w przypadku których okazało się to możliwe, najbardziej przydatne okazały się polubienia profili muzycznych. Były to: Kings of Leon, Black Sabbath, Megan Fox, Madonna, Rihanna, Korn, My Chemical Romance, Pink, Drake, Shakira czy Taylor Swift. Wykorzystano też polubienie aktora Vina Diesela. Wzięto również pod uwagę polubienia zaliczone do kategorii inne - „How I Met Your Mother” (serial) i „The Lord of the Rings Trilogy" (film).

Poniższy wykres odzwierciedla liczbę stron wskazanych w podsumowaniu badania, na podstawie której algorytm dokonał analizy prowadzącej do określenia preferencji seksualnych.

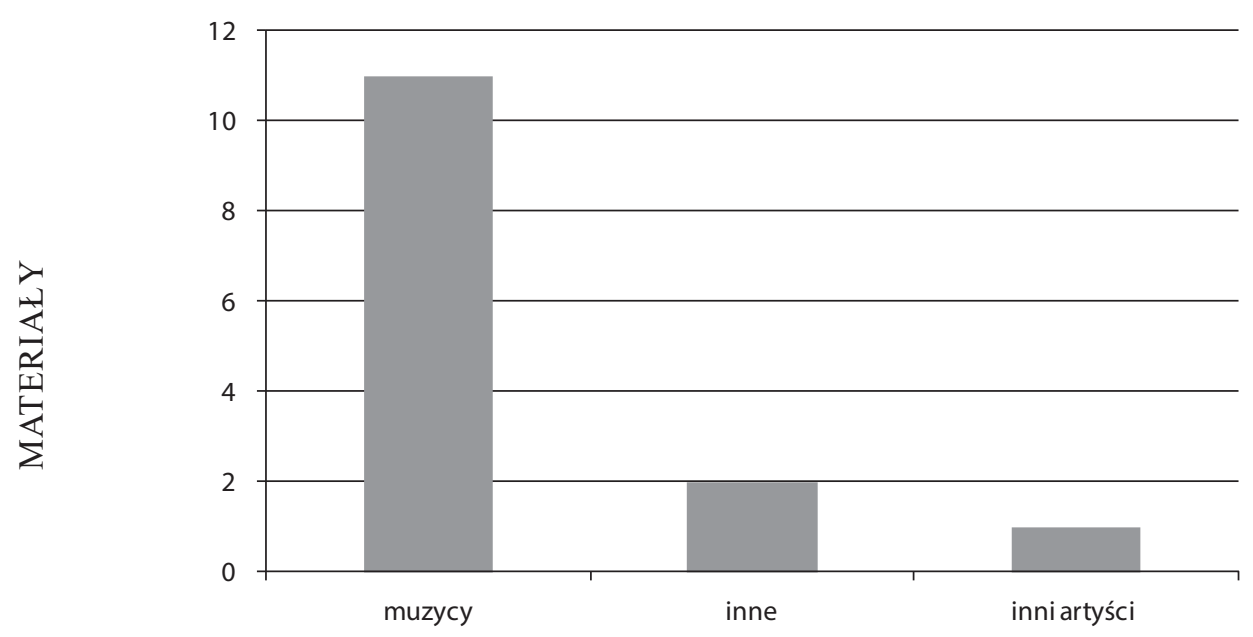

Wykres 3. Polubienia świadczące o preferencjach seksualnych

Źródło: badania własne.

Wnioskowanie odbywało się w tym przypadku na podstawie niewielkiego zestawu polubień. Jest to z pewnością jeden z powodów, dla których wskazania okazały się błędne - osoby heteroseksualne zostały posądzone o homoseksualizm, o którym miało świadczyć na przykład polubienie takich muzycznych profili, jak: Pearl Jam, Disturbed, Korn, My Chemical Romance, Pink, Shakira, Drake czy Taylor Swift. 
Do określenia statusu związku wykorzystano podobny, choć nieco rozszerzony zestaw polubień. W zbiorze znalazła się firma MAC jako jedyna strona z kategorii produktów kosmetycznych oraz Starbucks z branży spożywczej, pozostałe to: muzycy - My Chemical Romance, Snoop Dogg, Taylor Swift, AC/DC, Evanescence, Korn, Tyga, Disturbed, Black Sabbath, Alice in Chains, Nicki Minaj, Eminem; inni artyści - Vin Diesel, Stephen King, Megan Fox oraz Kim Kardashian; media - ANTM („American Next Top Model”) x 2. Natomiast w kategorii inne: David Beckham, „Inception” x 2, „The Simpsons”, „How I Met Your Mother”.

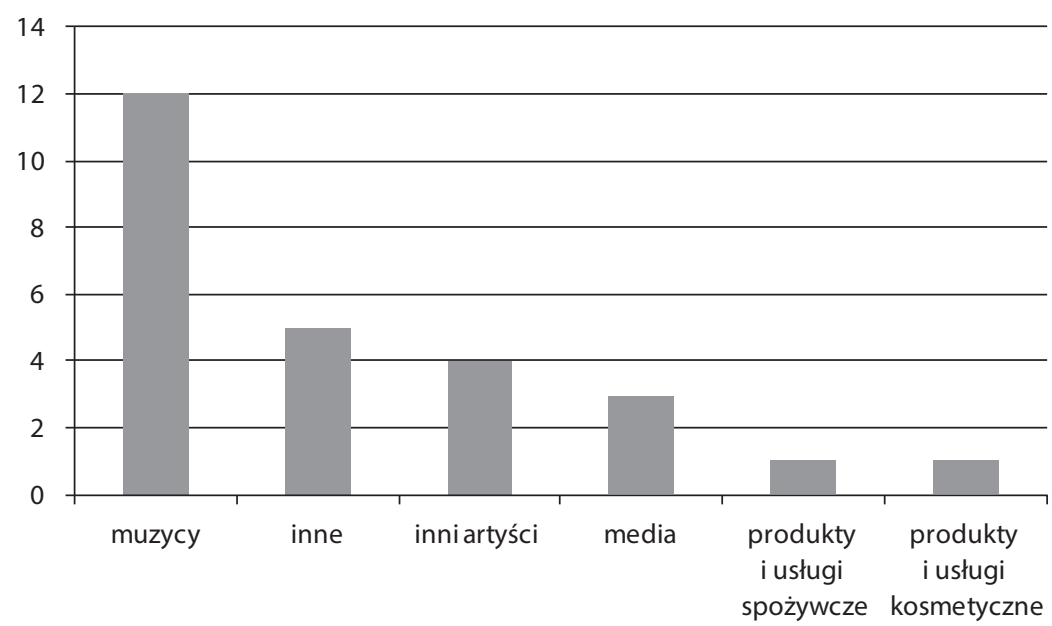

Wykres 4. Polubienia świadczące o byciu w związku

Źródło: badania własne.

O tym, że jesteśmy w związku, miało świadczyć na przykład polubienie kosmetyków MAC, kawiarni Starbucks, muzyków Disturbed, My Chemical Romance, Tyga, Snoop Dogg, Eminem, Drake, artysty Vina Diesela czy kreskówki „The Simpsons". Zaś o byciu samotnym słuchanie Black Sabbath, Evanescence, AC/DC, Taylor Swift, Drake'a, T.I., Tygi, Nicki Minaj, ale też obserwowanie profilu piłkarza Davida Beckhama czy artystki Megan Fox. Na duże prawdopodobieństwo posiadania małżonka miały zaś wskazywać polubienia profilu Alice in Chains czy Korn, seriali „Futurama” i „How I Met Your Mother”, ale też na przykład Stephena Kinga.

\section{Zaangażowanie $w$ polityke}

Na podstawie naszych polubień starano się również przewidzieć nasze zaangażowanie i preferencje polityczne. Podobnie jak w innych przypadkach profilowanie zostało oparte głównie na polubieniach stron muzycznych. 


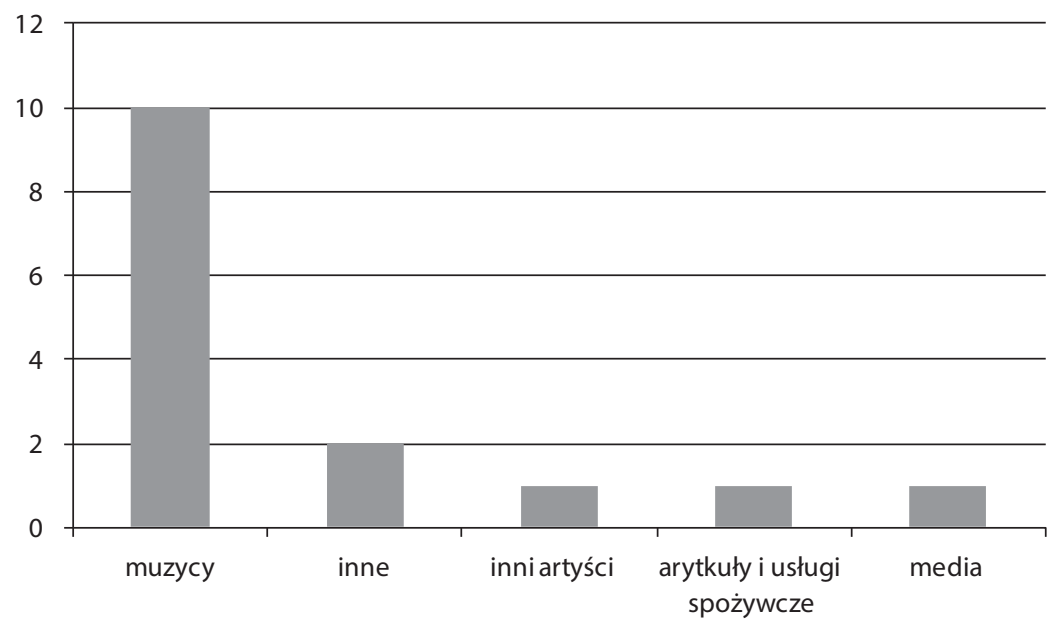

Wykres 5. Polubienia świadczące o stopniu zaangażowania w politykę

Źródło: badania własne.

Na duże zaangażowanie polityczne miały wskazywać polubienia takich zespołów muzycznych, jak: Foo Fighters, Rage Against the Machine, T.I., filmów: „The Lord of the Rings”, „Pretty Little Liars”, amerykańskiego reality show „America’s Next Top Model" czy sieci kawiarni Starbucks. O niewielkie zaangażowanie polityczne podejrzewano zaś zwolenników Pearl Jam, Roba Zombie, AC/DC, Nickelback, Pink, Eminema oraz Snoop Dogga czy wielbicieli aktorki Megan Fox.

O liberalne nastawienie podejrzewano użytkowników sympatyzujących z takimi muzykami i zespołami, jak: Pink Floyd, AC/DC, Nickelback, Korn, Nicki Minaj, filmem „Inception”, amerykańską gwiazdą Kim Kardashian czy magazynem National Geographic. O konserwatyzm posądzano zaś zwolenników Roba Zombie, Rage Against the Machine, Metalliki, Snoop Dogga, T.I. czy, co dość zaskakujące, Madonny. Konserwatyzm cechuje też z reguły tych, którzy lubią takie filmy, jak „The Simpsons” czy „The Lord of the Rings”.

\section{Krytyczna analiza skuteczności działania algorytmu}

Podstawą oceny działania algorytmu do profilowania osób powinna być jego skuteczność - generowanie danych jak najbliższych prawdy. Najłatwiej o taką ocenę w odniesieniu do czynników obiektywnych, łatwych do zweryfikowania w przypadku uczestników badania. I tak okazało się, że algorytm stworzony przez Kosińskiego i jego współpracowników dobrze radzi sobie z odgadywaniem wieku użytkowników Facebooka na podstawie analizy cyfrowych śladów w postaci polubień i postów. Wszystkie badane osoby zostały przyporządkowane do właściwego przedziału wiekowego, a odchylenie nie było większe niż trzy lata. W kontekście faktu, że oso- 
by rejestrujące się na Facebooku i tak podają swój wiek (choć nie zawsze zgodnie z prawdą, zwłaszcza dzieci zawyżają swój deklarowany wiek, by móc w ogóle zarejestrować się na tej platformie), należy to jednak uznać za umiarkowany sukces.

Zdecydowanie gorzej algorytm poradził sobie z określeniem płci i preferencji seksualnych. Spośród czterech uczestników badania zakwalifikowanych do sporządzenia pogłębionego profilu na podstawie polubień tylko w przypadku trzech wskazano właściwie płeć użytkownika - choć w opisie wyników można znaleźć informację, że chodzi o naszą płeć psychologiczną, a nie biologiczną. Algorytm określał też płeć w badaniu ogólnym - na podstawie postów i polubień. W tym badaniu statystyki wypadły jeszcze gorzej - na sześć osób płeć prawidłowo określono jedynie w przypadku połowy badanych. Tylko w przypadku trzech osób algorytm właściwie odczytał preferencje seksualne.

Ciekawie wygląda również zestawienie wyników uzyskanych na podstawie danych pozyskanych z portalu Facebook i tych otrzymanych w wyniku testu psychologicznego, który wypełnili wszyscy uczestnicy badania. Uzyskane rezultaty powinny być bardzo zbliżone, biorąc pod uwagę fakt, że to właśnie zagregowane dane osób, które wypełniły test i udostępniły go potem grupie badawczej Michała Kosińskiego, posłużyły do stworzenia algorytmu umożliwiającego wygenerowanie naszego profilu psychologicznego jedynie na podstawie naszej aktywności na portalu Facebook.

Jeżeli chodzi o badania prowadzone przez autorów artykułu, okazało się, że rzeczywiście uzyskano w większości przypadków wyniki zbliżone, choć nie brakowało i takich przypadków, w których znacząco się one różniły. Różnice powyżej 20 punktów procentowych zaznaczono.

Tabela 2. Porównanie wyników profilowania na podstawie aktywności na portalu Facebook i w wyniku przeprowadzenia testu psychologicznego poszczególnych osób biorących udział w badaniu ${ }^{1}$

\begin{tabular}{|l|c|c|c|c|c|c|c|c|c|c|}
\hline & A1 & TP1 & A2 & TP2 & A3 & TP3 & A4 & TP4 & A5 & TP5 \\
\hline Otwartość & $44 \%$ & $56 \%$ & $76 \%$ & $47 \%$ & $47 \%$ & $52 \%$ & $34 \%$ & $47 \%$ & $50 \%$ & $47 \%$ \\
\hline Sumienność & $69 \%$ & $45 \%$ & $69 \%$ & $43 \%$ & $43 \%$ & $41 \%$ & $56 \%$ & $43 \%$ & $50 \%$ & $42 \%$ \\
\hline Ekstrawersja & $38 \%$ & $45 \%$ & $11 \%$ & $30 \%$ & $41 \%$ & $30 \%$ & $79 \%$ & $47 \%$ & $60 \%$ & $41 \%$ \\
\hline Ugodowość & $56 \%$ & $39 \%$ & $34 \%$ & $24 \%$ & $38 \%$ & $36 \%$ & $42 \%$ & $39 \%$ & $42 \%$ & $37 \%$ \\
\hline Neurotyczność & $46 \%$ & $46 \%$ & $92 \%$ & $42 \%$ & $54 \%$ & $56 \%$ & $44 \%$ & $46 \%$ & $34 \%$ & $54 \%$ \\
\hline
\end{tabular}

Źródło: badania własne.

1 Jedna z osób wchodzących w skład zespołu badawczego nie wypełniła testu psychologicznego i z tego powodu nie została uwzględniona w zestawieniu. 
Jeśli weźmie się pod uwagę fakt, że wynik $50 \%$ to wartość przeciętna, to w skrajnych przypadkach w wyniku działania algorytmu dana osoba została oceniona jako typowy introwertyk, podczas gdy wyniki testu psychologicznego wskazywały, że jest typowym ekstrawertykiem.

\section{Podsumowanie}

„Na podstawie lajków z Facebooka algorytm jest w stanie przewidzieć ze skutecznością od 60 do 93\% fakty na temat życia każdej jednostki" - tłumaczył dr Michał Kosiński na jednym ze spotkań branżowych. - „Na podstawie 70-100 lajków algorytm jest w stanie zdobyć podobną wiedzę na temat jednostki, co jej rodzina. Na podstawie 250 lajków system będzie znał nas lepiej niż małżonek" w mediach nie brakuje wypowiedzi Kosińskiego utrzymanych w podobnym tonie (Ba 2018). Należy przyznać, że wizja możliwości profilowania naszej osoby na podstawie tak niewielkiej liczby cyfrowych śladów na tym popularnym portalu społecznościowym może zaniepokoić niejednego użytkownika. Z przeprowadzonych przez nas badań wynika jednak, że stworzony algorytm nie jest aż tak precyzyjny, jak wskazują jego twórcy, zwłaszcza jeśli chodzi o osoby z krajów spoza anglosaskiego kręgu kulturowego.

Pierwszą obserwacją, jaką udało się nam poczynić, jest ta, że profilowanie odbywa się głównie na podstawie polubień popularnych anglojęzycznych profili międzynarodowych, podczas gdy użytkownicy Facebooka w Polsce bardzo często swoją aktywność koncentrują na polskich profilach, choćby ze względu na brak znajomości języka angielskiego. Stworzenie pogłębionego profilu psychologicznego na podstawie tzw. polubień jest więc możliwe jedynie w przypadku osób, których aktywność na Facebooku jest duża i obejmuje takie „międzynarodowe" polubienia. W przypadku dwóch osób biorących udział w badaniu stworzenie takiego raportu okazało się niemożliwe. Osoby korzystające z Facebooka nieco rzadziej od innych bardzo trudno jest „prześwietlić” za pomocą stworzonego narzędzia badawczego. Należałoby więc podać w wątpliwość stwierdzenie Kosińskiego, że „70 polubień wystarcza, aby przewidzieć znajomość charakteru danej osoby lepiej niż jej przyjaciel”" (Moll 2018). Staje się ono prawdziwe dopiero wtedy, gdy zrobimy zastrzeżenie, że będą to określone, brane pod uwagę przez algorytm, polubienia konkretnych profili.

Czy to znaczy, że tak naprawdę nie ma się czego obawiać? Niestety tego nie można powiedzieć. Stworzone narzędzie z pewnością może być udoskonalane wraz z rosnąca liczbą danych wprowadzanych do systemu, a większość osób biorących udział w badaniu oceniła stworzony przez aplikację psychologiczny jako „,zaskakująco trafny” w wielu aspektach, zgłaszając zastrzeżenia do pojedynczych nieścisłości. Uzyskane wyniki, choć dalekie od precyzji, mogą być - jak wykazała afera z Cambridge Analytica - wykorzystane w sposób dla użytkowników mediów społecznościowych niebezpieczny. Nawet tak niedoskonała ocena naszego 
profilu psychologicznego może bowiem zostać wykorzystana do przesyłania nam treści dużo lepiej dopasowanych, niż było to do tej pory możliwe.

Kwestia ochrony naszych danych gromadzonych w portalach społecznościowych, przy jednoczesnym umożliwianiu naukowcom prowadzenia badań, stanowi dla współczesnego świata nie lada wyzwanie. Na razie możliwość profilowania za pomocą stworzonego przez zespół Kosińskiego narzędzia została zablokowana.

\section{Bibliografia}

Ba (2018). To koniec prywatności? Tak twierdzi Polak, który stworzył algorytm wykorzystany przez Cambridge Analityca [http://forsal.pl/lifestyle/nauka/artykuly/1118015,to-koniec-prywatnosci-tak-twierdzi-polak-ktory-stworzyl-algorytm-wykorzystany-przez-cambridge-analityca.html?test_login=elastic; 16.04.2018]

Costa R., McCrae O. (1992). An Introduction to the Five-Factor Model and Its Applications. Journal of Personality, vol. 60(2), s. 175-215.

Ćwiklak D. (2018). Facebook okazał się wyborczą bronią masowego rażenia. Newsweek [http://m.newsweek.pl/biznes/cambridge-analytica-jak-firma-od-danych-manipulujewyborami,artykuly,425016,1.html; 21.03.2018].

Elizabeth V. (2013). Interview with Michal Kosinski [https://blog.ometria.com/bid/317126/ Interview-with-Michal-Kosinski; 19.01.2018].

Europejski Trybunał Praw Człowieka (1950). Europejska Konwencja Praw Człowieka [https:// www.echr.coe.int/Documents/Convention_POL.pdf; 14.10.2018].

Gluckman N. (2018). Facebook Says It Will Help Academics Use Its Data. Here's How That's Supposed to Work. The Chronicle of Higher Education [https://www.chronicle.com/article/ Facebook-Says-It-Will-Help/243126; 13.04.2018].

Kosiński M. (2018). Dr Michal Kosinski [http://www.michalkosinski.com/home, 19.01.2018].

Łódzki B. (2016). Narzędzia internetowe w transnarodowych badaniach medioznawczych. W: K. Kopecka-Piech, K. Wasilewski (red.). Lokalne, regionalne, transnarodowe (s. 139157). Gorzów Wielkopolski.

Maroszok W. (2018). RODO, czyli ochrona danych 2.0. Nowe unijne przepisy oznaczają trudności dla przedsiębiorców [https://businessinsider.com.pl/firmy/przepisy/rodo-gdpr-regulacje-o-ochronie-danych-osobowych-zmiany-w-firmach/21p6svs; 14.10.2018].

mih, pcg (2018). Cambridge Analytica ogłasza zamknięcie. Firma manipulowała danymi użytkowników Facebooka i pomogła w zwycięstwie Trumpa [http://wyborcza. pl/7,75399,23350123, cambridge-analityca-oglasza-zamkniecie-manipulowala-danymi. html?disableRedirects=true; 19.06.2018].

Moll J. (2018). Na podstawie polubień na Facebooku można stworzyć profil psychologiczny [https://tylkonauka.pl/wiadomosc/na-podstawie-polubien-na-facebooku-mozna-stworzyc-profil-psychologiczny; 25.05.2018].

Nowak J. (2017). Polityki sieciowej popkultury. Lublin.

Parlament Europejski, Rada UE (2016). Rozporządzenie Parlamentu Europejskiego i Rady (UE) 2016/679 z dnia 27 kwietnia 2016 r. w sprawie ochrony osób fizycznych w związku z przetwarzaniem danych osobowych i w sprawie swobodnego przepływu takich danych oraz uchylenia dyrektywy 95/46/WE [https://giodo.gov.pl/pl/569/9276; 14.10.2018].

Rada Europy (2014). Guide to human rights for Internet users [https://rm.coe.int/16804d5b31; 14.10.2018]. 
Rada Europy (2016). Recommendation on Internet freedom [https://search.coe.int/cm/Pages/ result_details.aspx?ObjectId $=09000016806415 \mathrm{fa} ; 14.10 .2018]$.

Stanford Graduate School of Business (2018). Dr. Michał Kosiński [https://www.gsb.stanford. edu/faculty-research/faculty/michal-kosinski, 19.01.2018].

Szymaniak M. (2017). Polak odkrył polityczną bombę atomową. To koniec demokracji, jaką znamy? [https://www.tvn24.pl/magazyn-tvn24/polak-odkryl-polityczna-bombe-atomowa-to-koniec-demokracji-jaka-znamy,79,1628, 19.01.2018].

\section{STRESZCZENIE}

W artykule poddano analizie działanie narzędzia ApplyMagicSauce.com, stworzonego przez naukowców do profilowania użytkowników mediów społecznościowych. Stało się o nim głośno, gdy mechanizm jego działania został wykorzystany przez firmę Cambridge Analytica, zaangażowaną w kampanię prezydencką Donalda Trumpa i zwolenników wystąpienia Wielkiej Brytanii z Unii Europejskiej. Grupa sześciu osób, składająca się z wykładowcy oraz studentów dziennikarstwa i komunikacji społecznej, postanowiła poddać się badaniu z wykorzystaniem tego narzędzia, udostępniając dane ze swoich prywatnych profili na portalu Facebook. Celem, jaki sobie postawiono, było wykazanie, jak działa takie narzędzie, i krytyczna analiza jego skuteczności. Badanie przeprowadzono pod koniec 2017 roku.

Słowa kluczowe: Internet, Facebook, media społecznościowe, algorytm, Big Data 